\title{
TOURISM, MODERNITY AND SPIRIT OF THE PLACE: A CASE STUDY OF RELIGIOUS HERITAGE SITE MANAGEMENT IN LAMPHUN, THAILAND
}

\author{
Saranphat Wongput \\ Department of Tourism, Faculty of Humanities, Chiang Mai University
}

\begin{abstract}
These Genius Loci or the concept of 'Spirit of place' has been an essential factor that all religious site managers need to take into consideration, because such concept may help to preserve the integrity of the place both for worshipers and tourists. The advent of modernity and tourism at times has implications on cultural fabric of sacred cultural landscape as sacred sites have increasingly been used in tourism promotional campaigns. Alteration and modification of religious space for use and for tourism purposes is inevitable. This research draws on the religious city of Lamphun, a town located in northern Thailand, as a case study. The research addresses the question "To what extent has tourism and modernity affected the 'spirit of place' of religious heritage sites?" The research is based on qualitative methods of observation and in-depth interviews at significant religious sites in Lamphun. Research findings may contribute to the debates over the balance between conservation and development paradigms.
\end{abstract}

Keywords: religious tourism, cultural heritage management, Spirit of Place, Thailand

\section{INTRODUCTION}

\section{Research background}

The concept of Genius Loci or the 'Spirit of the place' has been seen as an integral part of cultural heritage management as it offers a comprehensive understanding of monuments as well as the surroundings. Spirit of place is physical and spiritual values that gives meaning and values to a place. In other words, Spirit of Place include the integrity of both tangible (building, site, route, objects) and intangible elements of the place, the meaning, emotion and mystery (Quebec Declaration 2008).

However, the advent of modernity and tourism at times has implications on cultural fabric of sacred cultural landscape. Tangible heritage and intangible heritage has already been transformed as a consequence of changing ways of life. While tourism has become an integral part of the regional development plan, sacred sites have increasingly been used as tourism resources and exposed to the process of transformation and adaptation to ease visitors' convenience.

This research draws on the religious city of Lamphun, located in northern Thailand, as a case study. Lamphun has been widely known as a religious town since the early times and it now still contains a number of significant religious features, such as the Buddha relic shrines and the Buddha footprints. Intangible heritage has also been transmitted to current generation.

Lamphun was the case study for my thesis in 2011. The findings suggest that religious heritage in Lamphun is valued, understood, interpreted and managed differently by different parties. Since 2011, I have been involved in many tourism development projects that included Lamphun in the study area. Therefore, the knowledge about Lamphun in this paper comes from my longitudinal experience since my first field survey in 2009.

This research paper addresses the main question "To what extent has tourism and modernity affected 
'spirit of the place' of religious heritage sites?" Sub questions include:

How has tourism influenced religious heritage management in Lamphun?

What are visitor motivations and behaviours?

What parties are involved in determining 'spirit of place'?

How has tourism and modernity affected 'spirit of the place' at religious heritage sites in Lamphun?

\section{Site Background}

Lamphun has been a renowned pilgrimage destination in Northern Thailand (see figure 1). The city is full of tangible religious heritage, such as the Buddha relic shrine, Phrathat Haripunchai (Phrathat means the relic shrine; Haripunchai is the former name of Lamphun), and a number of noteworthy temples within the walled city and scattered across the outer districts of Lamphun. Lamphun's intangible religious heritage has also attracted visitors to the province, especially during the religious festivals, such as the Relic Shrine Bathing Ceremony. In addition, lamphun has been known as home of Krubas. Krubas are honourable monks whose lives were dedicated to Buddhist practices (Buadang 2002:1; Cohen 2001:227). Krubas were the most respected persons in Lanna society and, as a community's spiritual leaders; they maintained social norms and values (Buadaeng n.d; Santayos 2010: 82) One of most famous Krubas that resided in Lamphun was Kruba Sri Wichai who was widely known as the 'saint' of Lanna (The Northern Thai Kingdom) as he was the head of many temple and monastery development and renovation projects.

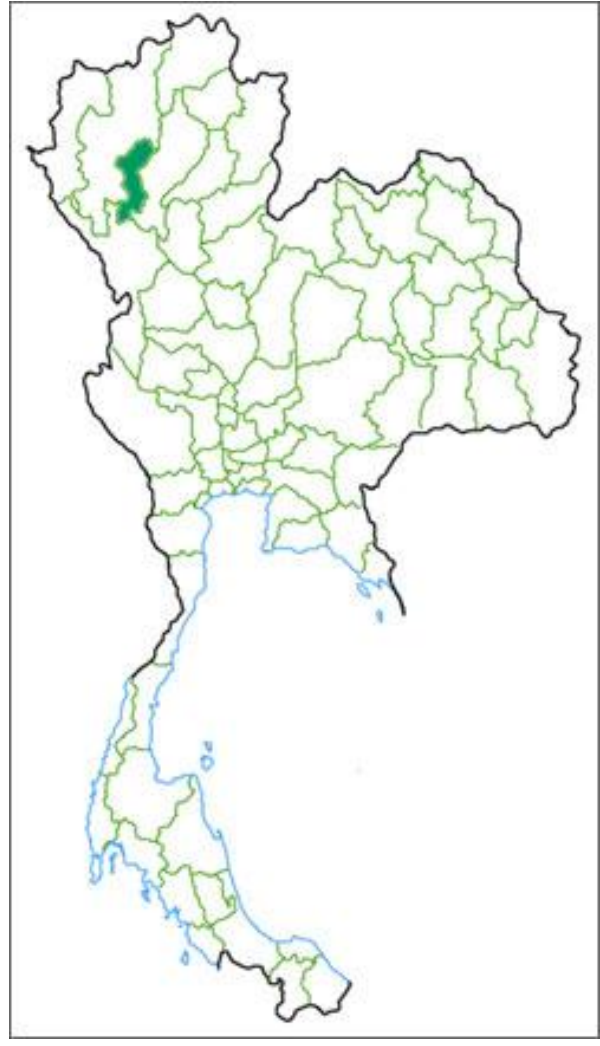

Figure 1 Location of Lamphun in Northern Thailand. Source: Thailandmap.net

Lamphun's releligious heritage has been frequently used in tourism promotional campaign (Saengphueng, 2014) as well as to empower local residents' awareness of local identity. Religious significance has been emphasized in many other contemporary events, such as the car rally that the route passed through many temples that have relations to the past Krubas across the province of Lamphun.

\section{Literature Review}

There is a wide array of literature that addresses the significance of 'spirit of place' in cultural heritage management. The paper first discusses the current situations of religious heritage in Thailand, particularly the issues of competing discourses between Western and Eastern conservation ethics. Then, it proceeds to discuss the concept of 'spirit of place', authenticity and The implications of tourism on cultural heritage.

\section{Spirit of the place and Authenticity}

Central to this research is the concept of 'Spirit of the Place'. According to the Quebec Declaration, spirit of 
place is 'The tangible (buildings, sites, landscape, routes, objects, etc.) and Intangible elements (memories, narratives, written documents, ritual, festivals, traditional knowledge, values, textures, odours, etc.), or in other words, the physical and the spiritual elements that gives meaning and values to the site' (Quebec Declaration, 2008).

The concept of 'Spirit of Place' has been reconceptualised over the past decade in relation to the changing nature of conservation ethics in the academic world as intangible has increasingly been revognised as an integral part of heritage sites. The launch of Quebec Deaclaration in 2008 was aimed to explore the relationship between tangible and intangible heritage and recognise the dynamic nature of the concept (Quebec Declaration, 2008). Currently is it accepted that the 'Spirit of Place' is multiform and often varies over time and from one culture to another and thus it needs to be understood by the processes of identification, safeguarding and transmitting.

'Spirit of Place' is an important concept for religious site management as the preservation of material authenticity and preservation of intangible values attached to the sites means the life of the site is prolonged as a religious compound. For tourists, 'Spirit of Place' is the concept that creates a kind of atmosphere that gives them unique experience and better understanding of the site. For example, when visitors walked into a cathedral, they would expect to have peaceful and holy experience or similar kind of experience that connect the mundane to the spiritual space.

\section{Modernity and Tourism}

Tourism has long been seen as a series of activities that have a close relationship with Modernity. The concept of 'Modernity' has been associated with social changes that occurred in Europe in the second half of the nineteenth century, such as impacts of industrilisation and urbanisation. Increasing mobility and changing perception of the world and the environment are also consequences of modernity (Eyerman, 1992). These changes also include increased movement of goods, capital, people, and information among formerly discrete populations. In terms of arts and literature, modernism means the new sense of individuality, future orientation, and creative possibility among individuals and community of interest (Eyerman, 1992)

Modernity was thought to be a consequences of social changes bounded to Europe following the industrial revolution and technological innovation (Giddens, 1991), however, it is accepted that the impacts of modernity has become globalised. Like other places, Lamphun has been affected by the advent of modernity. The construction of the railway in 1903 and the motorway to Chiang Mai significantly brought about changes to Lamphun. The Chiang MaiLamphun basin experienced great cultural changes following the expansion of the local economy and improved transportation systems (Sethakul, 2009: 309). Tourists started to arrive in Lamphun, which is located on the way from Bangkok to Chiang Mai. Modern tourism activities have subsequently been developed.

\section{Religious Heritage and Religious Tourism in Thailand}

Buddhism has been one of the most significant ideologies in Thailand as it has been used as the central ideology and foundation of cultures at both central administrative and local level. Modern Thailand is a Buddhist state and much of the driving force for domestic tourism is Buddhist pilgrimages, which may include general visit to reliquaries and famous wats throughout the country (Byrne 1993).

Religious tourism, including pilgrimage, is embedded within heritage tourism and mass tourism activities (Rotherham, 2007: 65). It includes the visit for the purpose of participating in religious ceremonies and conferences, and the visit to local, regional, national, and international religious centres (Rinschede, 1992: 52). From a spiritual perspective, an experience at religious sites is associated with someone or something that believers venerate. Sociologically it may provide cultural access to sacred art and sculpture, which may attract atheists or those of other religions as well as the devout of a particular faith (Rotherham, 2007: 65).

Smith (1992) argues that the relationship between tourism and religion may be conceptualised as a continuum depending on the degree of intensity of 
religious motivation (see figure 2). Sacred pilgrimage, a journey driven by faith, religion and spiritual fulfillment, lies at one extreme; at the other extreme lies the secular tourist who may seek to satisfy some personal or spiritual need through tourism.

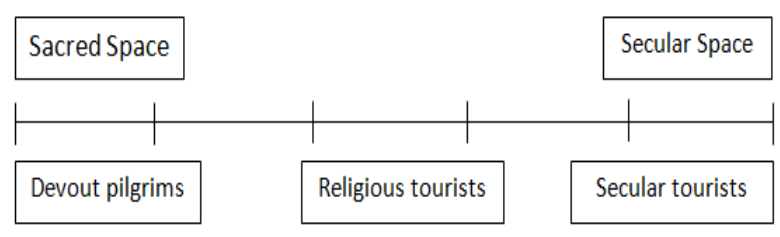

Figure 2 Continuum of a relationship between the sacred and the secular

Source: Timothy 2011: 386 (after Smith 1992)

Lamphun is home to many temples and sacred sites that are pilgrimage destinations. Wat Phrathat Haripunchai, a temple that hosts the Buddha reliquary in Lamphun, has always been under royal patronage throughout the history, and it has been declared one of the most significant 'national' Buddhist stupas of 'Thailand' (Synchron 2009b). Tourists and pilgrims from different provinces and regions visit the relic shrines during the annual festival and authentic spiritual feelings are still in the atmosphere. The relic shrine has always been the core attraction of Lamphun. Recently, any festival or ceremonies related to the relic shrines have also been promoted as tourism events. Local authority also set up a tram route that starts from Wat Phrathat Haripunchai and extended through other religious sites across the main district of Lamphun.

\section{Competing Discourses in Religious Heritage Management in Lamphun}

Perception of heritage is like the perception of 'Spirit of Place'. It varies temporally and geographically. Lamphun's heritage is perceived differently by its communities. There are significant discourses that shape the way heritage is managed in Thailand, and particularly in Lamphun. According to my thesis (Saengphueng, 2011), the major discourses are: firstly, the traditional religious discourse, which is mainly based on Buddhist ideologies with some influence from spiritual cults; secondly, the royalistnationalist discourse underlying national cultural policies implemented by the central government; and, finally, the Western conservation ethics or Western
AHD. However, this does not mean that there is no other discourse that shapes the way people understand and perceive heritage.

These competing discourses shape the way people understand and manage religious heritage. For example, the Head Monk who has full authority over the maintenance of a temple may be adhered to the local/traditional discourse that favours the transmission and continuity of religious practices with less consideration of material authenticity. He might call for the renovation of an ancient pagoda to create an opportunity for the followers to donate as their 'good deeds'. Government agencies are often influenced by National planning policies. Their actions on religious heritage are likely to follow government's agenda of the time. Local residents, believers and pilgrims, that comes from different location may also perceive religious heritage differently according to their background and personal experience. This variation often add conflicts religious heritage. Although the Head Monk is the authorised person to determine the faith of religious heritage under his care, local communities and believers also see themselves as owner of such religious heritage and thus entitled to express their opinions and their needs.

The advent of tourism also add more conflicts to religious site as more and more 'tourists' may enter into a 'sacred space' and have no idea about 'Dos and Don'ts' in the religious space. Local residents and host communities also have various responses to tourism development. In addition to the issue of conservation, many religious sites now have to deal with visitor management on-site. Implementing a repressive measure to control visitor flow may on one hand preserve the 'spirit of place' in terms of general atmosphere. On the other hand, pilgrims and visitors may feel that they have no freedom and feel uncomfortable at the religious space as expected. It is essential for local stakeholders to find a balance between conservation and development and also between tourism/ modernity and original 'Spirit of Place'.

\section{METHODOLOGY}

The research was based on a range of data collection methods. These methods comprise documentary 
evidence, such as government policy documents, archives, records of events, papers of conference proceedings, local newspaper articles and other secondary sources. In addition data was used from a questionnaire survey on 'Visitor Motivation' survey conducted in 2015. The survey focused on visitors' motivations, perceptions, experiences and expectations at religious heritage sites. Qualitative interviews were another data collection method used to explore both the ethnographers' and experts' viewpoints. Groups of interviewees included: local government officials, the head monks of significant temples on the tourist route, local residents, shopkeepers at religious heritage sites and visitors to the sites. Finally, participant observation was undertaken in different settings, at different religious sites, festive events, and at local organisations. Observation was also made at significant temples in Lamphun, including Wat Phrathat Haripunchai (the temple that hosts the Buddha relic shrine. It is located at the heart of the main district of Lamphun), Wat Mahawan (the temple that is famous for ancient Buddha amulets called 'Phra-Rod') Wat Jama Thewi ( the temple that hosts the pyramidal pagoda claimed to be the shrine of the first ruler of Lamphun), Wat Ton Kaew, Ku Chang - Ku Ma, Wat San Pa Yang Luang, Wat Phra Yuen, Wat Phra Puttabat Tak Pha, Wat Pa Nam, Wat Ban Pang, Wat Phra Puttabat Huay Tom and Chedi Sri Wiang Chai.

These sites may be roughly divided into two main groups: the city temple cluster and the en-route temple (see figure 3). Most of the significant temple and sacred sites are in the Muang (main) district, $\mathrm{Pa}$ Sang district and the $\mathrm{Li}$ district. $\mathrm{Li}$ was also an ancient town and when it became part of Lamphun, this district was home of many revered Krubas.

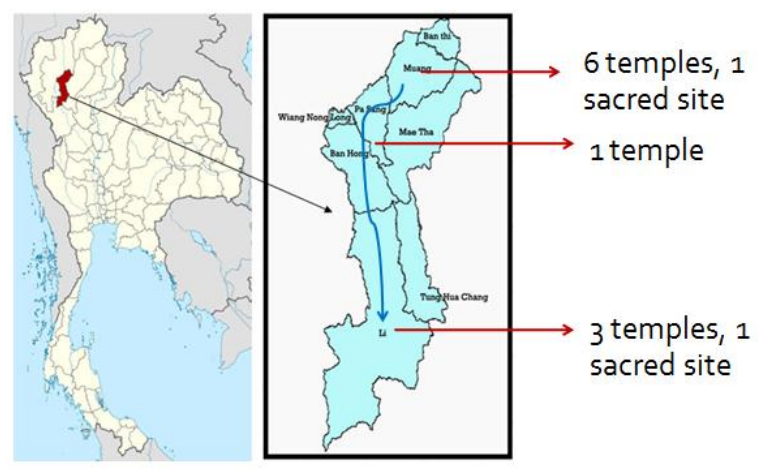

Figure 3 Two clusters of sample sites in three districts

\section{RESEARCH FINDINGS}

In order to understand how tourism and modernity has left impacts on 'Spirit of Place' at religious sites, I propose that the system of 'Spirit of Place' consists of four important elements: People, Place, tangible components and intangible components (see figure 4).

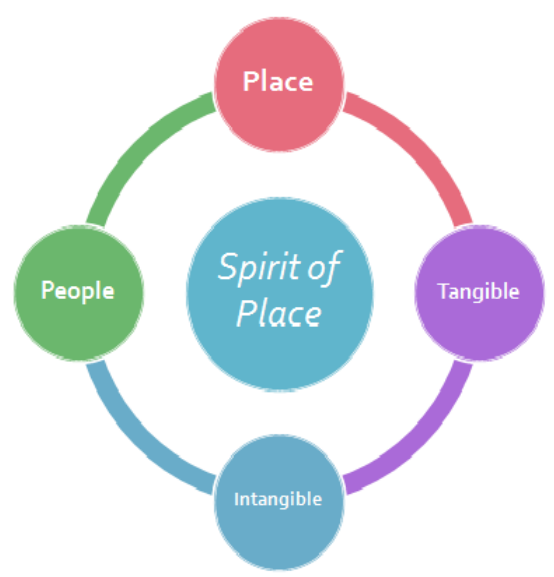

Figure 4 Spirit of Place is maintained if the balance between the four components is achieved.

People: visitors, surrounding, communities as well as carers of religious heritage.

Place: significance, management system, governance, regulations, policies, etc...

Tangible components: buildings, sites, objects, facilities, landscape, etc...

Intangible components: attached values, beliefs, atmosphere, ceremony, festivals, etc.

These four essential components need to be taken into consideration so as to keep the spirit of place intact.

\section{Tourism and Religious Heritage}

Tourism is one of the factors that emphasize the significance of Lamphun as a religious destination. However, Lamphun's religious significance has been well known by local and regional visitors before the advent of modern tourism. Kruba Sriwichai (18781938) was one of the most 'respected' Lanna monks at the turn of the twentieth century (Srisuwan, 1997; Buadaeng, 2002.; Chanamool, 2010). His residence in Lamphun attracted a number of followers. Phrathat Haripunchai or the Buddha relic shrine also receives a large number of pilgrims each year. Some important relic shrines in Northern Thailand have been linked 
with the twelve-year animal cycle, and Lanna Buddhists feel obliged to make a pilgrimage to a particular shrine, depending on one's zodiac sign (Keyes, 1975: 73). Phrathat Haripunchai, which represents the 'chicken' year, also attracts a number of pilgrims ever since.

Lamphun was a famous stopping point for visitors to the north as it is located on the route from Bangkok to Chiang Mai. Modern tourism activities have subsequently been developed, especially at Pa Sang, a district famous for hand-woven cotton cloth. Pa Sang expanded significantly as it was used as a stopover point by tourists for lunch and the purchase of souvenirs. However, the construction of another larger superhighway diverted tourists away from the original route. Tourists only needed to travel through the outskirts of Lamphun without passing through the city. This diversion saved time and fuel for the journey to the north, but significantly affected Lamphun's tourism. This external change coincided with the passing away of many krubas, who used to be a magnetic power that attracts a vast number of believers to different places in Lamphun. Many temples in Lamphun that used to receive a large number of tourists every year gradually lost its popularity.

Currently, Lamphun has received much less number of tourists than its neighbour, Chiang Mai. Domestic excursions seem to be more influential compared to international tourism. In 2013, 94.3\% of visitors to Lamphun are domestic and only $5.7 \%$ are international. $70.7 \%$ of visitors are excursionists, whilst $29.3 \%$ are tourists that stayed overnight (Department of Tourism). Wat Phrathat Haripunchai is the main tourist destination. Other temples have received less number of tourists, but many local visitors. Religious heritage, either tangible or intangible, is widely used as tourism resources to attract visitors. There are two tram rides starting at 9.00 and 13.00 that take visitors to different religious heritage sites across the main district of Lamphun. Religious tourism is one of the key goals that local government aims to benefit from, apart from the promotion of agro-tourism and cultural tourism. Many of the tourism events are associated with Buddhist festivals or Buddhist religious sites.
Some important temples are funded by local government for the improvement of landscape and facilities. Most of the temples are self-funded through donation. When temples are open for visitors, much of the donation must be used for visitor management. Tourists and pilgrims are very hard to distinguished, as for Thai people merit -making can also be considered 'recreational' activities.

To conclude, tourism has given values and recognitions to religious heritage, but local communities and the temples still manage to control the tourism impact at this stage. There is no obvious sign of the favour ing tourism development over local use of religious site for spiritual purposes, but religious heritage has increasingly been promoted as tourism attractions.

\section{Visitor Motivation for Visit and Visitor Behavior}

The exploration of visitor motivation is essential as it tells us whether visitors to the sites will enhance the preservation of 'Spirit of Place' or act as ones who destroy the general sacred atmosphere. According to the result of the questionnaire survey, the majority of participants visit temple from their inner desire to make 'merit' or to pay 'respect' to the sacred structure, such as the relic shrine, or the Buddha footprints.

The reasons for choosing the temple are reputation of the place, personal connection or the locations of the temples are accessible. Almost 50\% chose the temple they visited because of it is located close to their homes. Approximately $32 \%$ chose to visit the temple because they were recommended by friends or relatives. $26 \%$ visited the site due to its reputation or the attached narratives. Over $40 \%$ of participants are local (lived in Lamphun).

Motivations generally are divided into push and pull factors. Push factors include inner desire that makes the travel happen. Pull factors are associated to the destinations. They are the attractiveness that makes visitors desire to visit. For the case of religious sites in Lamphun, it can be seen from the survey that inner motivation or the push factors definitely play a more significant roles than the pull factors. Thus, local visitors are not fussy about facilities. They do complain about toilets, coffee shops, or even car park. They expected more shades to sit and rest and reflects good deeds that they conducted. Visitors from other 
parts of the country pay more attention to physical authenticity and the landscape, but generally visitors are satisfied with the atmosphere of temples in Lamphun as they have experienced a more crowded and touristy atmosphere of temples in major cities like Chiang Mai and Bangkok.

To sum up, most of visitors to religious heritage have the quality of 'pilgrim' in themselves, although they may not consider themselves pilgrims or believers. Their motivations for visit are generally related to religious practice, and thus these motivations have strong control over their behaviour. These motivations often influence them to think less of surroundings, but pay more attention to what they are doing at the sites.

\section{Local communities and their roles in determining 'Spirit of Place'}

Local communities are important factors that will determine the spirit of place. According to my study for my thesis and my observation during the involvement in other projects, involved parties that play a role in determining the spirit of place may have different perceptions of 'Spirit of Place' as outlined below (see table 1 ):

Table 1 Parties that may play a role in determining the concept of 'Spirit of Place'

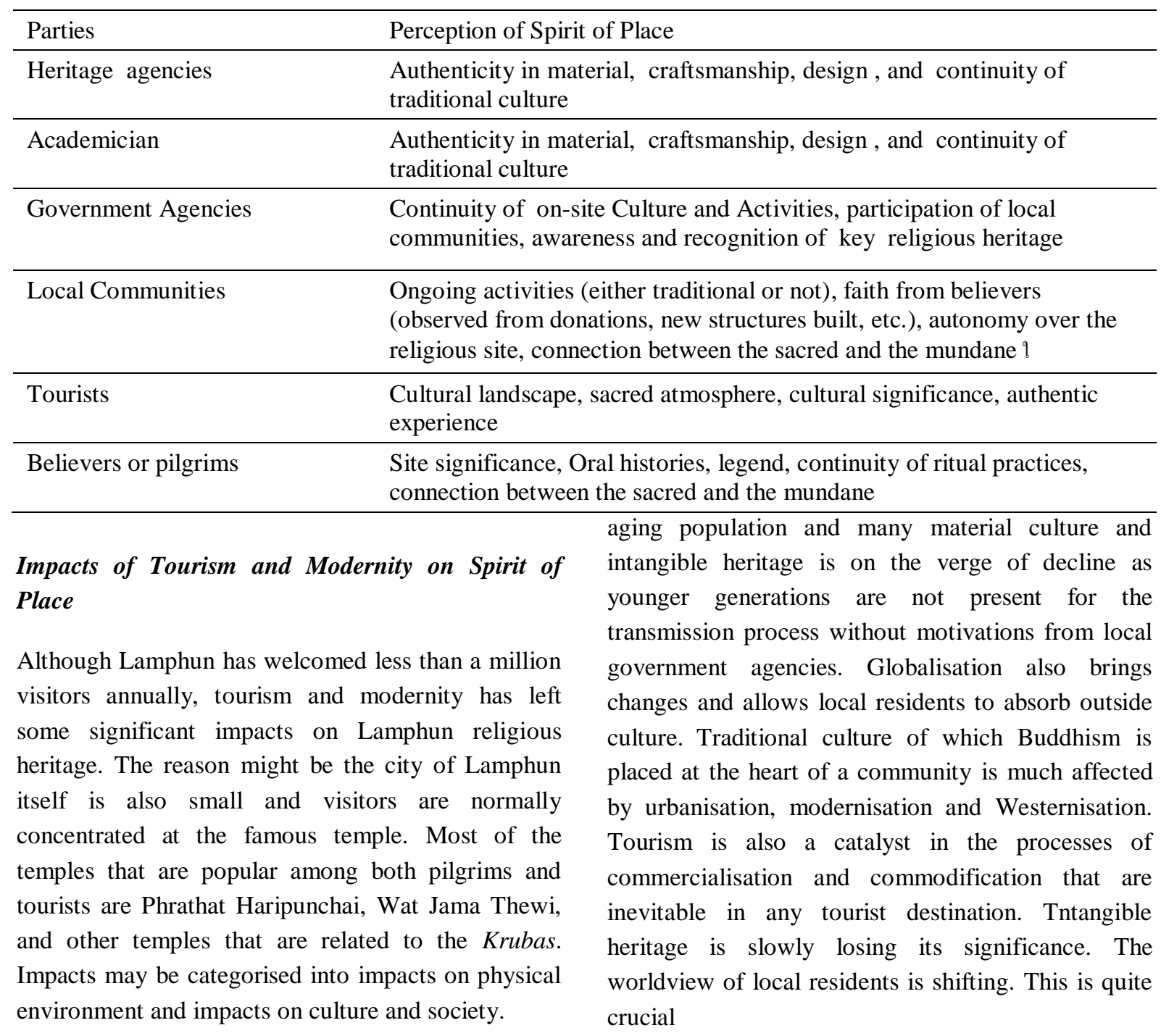

Modernity has led to changes of social structure and cultural diffusion. Lamphun residents have moved to Chiang Mai, a larger and more urbanised neighbor and a number of Lamphun residents commute to Chiang Mai for work. This results in the problem of

Regarding physical environment of the religious heritage, many on-site amenities for tourists e.g. museums, weaving centre were developed with the hope for visitors to spend more time learning about 
the site and having better experience. In many temples, communities do not see these structures as relevant to the religious compounds and the facilities were left unattended leading to the deterioration of such structures. Other facilities, such as coffee shops, viewpoints, social media check-in points and other decorations that are rather alienated have been installed at religious heritage sites. These additions may affect the sacred atmosphere at religious sites.

Many temples that formerly have a traditional environment are renovated into a completely different and modern styles as the Head Monk want his visitors to enjoy better facilities among the cries of local experts and academicians at the loss of cultural heritage.

\section{Discussion: Tourism, modernity and the future of religious tourism in Lamphun}

According to the research findings, Lamphun has long been perceived as a religious town, and the image of Lamphun as a religious town is still portrayed by local government and in the mass media. Local residents also believe the same. Thus the term 'religions', 'Buddhist' and 'Kruba' are still key words that are often used as part of the heritage discourse for tourism development and for community empowerment. Tourism not only generates income, but attracts visitors to the site. This prolongs the life of religious sites as a place of worship. Although the role of Buddhism and Buddhist practices in everyday life is changing, Lamphun's general atmosphere is still 'traditional' and 'authentic' compared to a more touristic neighbour, Chiang Mai.

Lamphun's religious heritage is still given much recognition from different communities in the province, thus each community attach meanings and values to such heritage. The way religious heritage are managed by different communities is often the best way

On one hand, preservation of material and atmospheric authenticity helps to preserve cultural values that may lead to sustainable management of the cultural resources. On the other hand, modernity leads to innovation. Social and cultural changes illustrate that such community is still active. Their heritage is still evolving and valued by host communities. If temples are not open to outside visitors but Buddhist pilgrims, or if innovative events are limited just to preserve traditional and sacred atmosphere, the number of temple users will are definitely declined as a consequence of social changes. Changes occur from within a community. Safeguarding of Spirit of the Place has to be a negotiation between involved parties, government agencies and local communities.

The determination of 'Spirit of Place' is like a cultural process that involves the process of meaning making between communities. The nature of cultural heritage is discursive and its management is even more so. The concept of 'Spirit of Place' that fits in with one context may not work properly in another context, where social and cultural factors are different and visitors to the sites may as well have different profile and bahaviours. Thus 'Spirit of Place' may be defined and re-defined by a range of communities as they negotiate their identities and sense of place.

\section{CONCLUSION}

Different parties are adhered to different concept of 'Spirit of the place'. Tourism does accelerate the changing nature of religious heritage, but maybe not the main factors that affects 'Spirit of the place'. Safeguarding of Spirit of the Place has to be a negotiation between involved parties, government agencies and local communities. The content and meaning of 'Spirit of Place' is not universally and all time true. One community must find the one concept that best suit their religious heritage management.

\section{REFERENCES}

BUADAENG, K., 2002, 'Kruba movements and the Karen in Northern Thailand: Negotiating Sacred Space and Identity', Cultural Diversity and Conservation in the Making of Mainland Southeast Asia and Southwestern China Regional Dynamics in the Past and Present, edited by in H. Yukio and T. Sayavomgkhamdy (Bangkok: Amarin Printing and Publishing Co. Ltd: 262-293).

BYRNE, D., 1993, The Past of Others: Archaeological Heritage Management in Thailand and Australia, Unpublished PhD Thesis, (Australian National University).

CHANAMOOL, S., 2010, 'Kruba Sriwichai: Ton Bun Lanna', in S. Malasam (ed.) Yong Lamphun: 
Yong World Heritage, Documents for the Seminar at Ban Wiang Yong 27 February-2 March 2010, Lamphun: Tambon Wiang Yong: 1-33. [in Thai]

EYERMAN, R.,1992, Modernity and Social Movement, Social Change and Modernity, Edited By Hans Haferkamp and Neil J. Smelser, (Berkeley: University of California Press).

GIDDENS, A., 1991, The Consequences of Modernity, (Cornwall: T.J. Press (Padstow) Ltd.).

ICOMOS 2008, Quebec Declaration on the Preservation of the Spirit of Place, 4th October 2008, Quebec, Canada.

KEYES, C. 1975, Buddhist Pilgrimage Centre and the Twelve-Year Cycle: Northern Thai Moral Order in Space and Time, History and Religions, 15(1):7189

NETNIYOM, S., 2009, Phrathat: Ku-sa-la-lak in Buddhism: From Idealist Geographical Landmarks to Network of Communities in Chiangmai-Lamphun Basin, (Chiangmai: Tarnpunya). [in Thai]

RINSCHEDE, G. 1992, Forms of Religious Tourism, Annals of Tourism Research 19(1): 51-67.

ROTHERHAM, I 2007, Sustaining Tourism infrastructures for Religious Tourists and Pilgrims within the UK, Religious Tourism and Pilgrimage Festivals Management, edited by R. Raj and N.D. Morpeth (Wallingford: CABI International)

SAENGPHUENG, S. 2011, Managing Religious Heritage, Competing Discourses of Heritage and Conflicts in Cultural Heritage Management: A Case Study of Lamphun, Unpublished $\mathrm{PhD}$ Thesis, Department of Archaeology, University of York.

SAENGPHUENG, S., 2014, Journey through the Holy Land: Exploring the Religious Discourse and Its Impacts on Tourism in Lamphun" Proceedings for the International Conference on Tourism and Development: Growth and Diversity (p. 338- 354), organized by Department of Tourism, Chiang Mai University, 29-30 August, 2014, Imperial Mae Ping Chiang Mai.

SANTAYOS,J., Khruba Sriwichai and the new Kruba cult from 1987-2007, Sinlapa Wattanatum 31(4):8195. [in Thai]

SETHAKUL, R., 2009, Western countries in Lanna and the implications on relationship with Siam, Document for the Seminar '200 years Lamphun: Development and revival, 18 April 2006 at Haripunchai National Museum, Lamphun: Haripunchai National Museum. [in Thai]

SMITH, V.L. 1992, 'Introduction: The quest in guest', Annals of Tourism Research, 19:1-17

SRISUWAN, C., 1997, 'Kruba Sriwichai movement', retrieved from http://www.thapra.lib.su.ac.th/objects/thesis/fulltext/t
hapra/Charnnarong_Srisuwan, page consulted 12/05/2009, unpublished master's thesis, Silpakorn University. [in Thai]

SWEARER, D., 2010, The Buddhist World of Southeast Asia, (Albany: State University of New York Press).

SYNCHRON, 2009, Lamphun's Master Plan for World Heritage Listing [in Thai]

WALLIPODOM, S., 2003, The meaning of 'the Great Relic Shrines' in the Siamese civilizations, (Bangkok: Muangboran). [in Thai] 